\begin{tabular}{l|c|c}
\hline ISSN: 0001-5113 & ACTA ADRIAT., & ORIGINAL SCIENTIFIC PAPER \\
AADRAY & 60(1): 25 - 40, 2019 & \\
\hline
\end{tabular}

\title{
Recent changes (2013-2017) in scyphomedusan fauna in the Boka Kotorska Bay, Montenegro (Southeast Adriatic)
}

\author{
Ivana VIOLIĆ ${ }^{1}$, Tjaša KOGOVŠEK ${ }^{2}$, Branka PESTORIĆ ${ }^{3}$, Vesna MAČIĆ ${ }^{3}$, \\ Ivona MILIĆ BERAN ${ }^{1}$ and Davor LUČIĆ*1
}

\author{
${ }^{1}$ University of Dubrovnik, D. Jude 12, 20000 Dubrovnik, Croatia \\ ${ }^{2}$ Marine Biology Station, National Institute of Biology, Fornače 41, 6330 Piran, Slovenia \\ ${ }^{3}$ Institute of Marine Biology, University of Montenegro, Dobrota bb, 85330 Kotor, Montenegro \\ *Corresponding author, e-mail: davor.lucic@unidu.hr
}

A semi- quantitative time series (2013-2017) was used to present the recent events of scyphomedusae appearance and abundance in the Boka Kotorska Bay, Montenegro, Southeast Adriatic. Six meroplanktonic species were recorded: Aurelia spp, Chrysaora hysoscella, Cotylorhiza tuberculata, Discomedusa lobata, Drymonema dalmatinum and Rhizostoma pulmo. Among them, C. hysoscella and $\mathrm{D}$. lobata dominated in the water column during winter and spring, forming dense aggregations in March and May, and February to May, respectively. Our description of the D. lobata blooms are actually the first known records of blooms for this species. C. tuberculata was observed in the Bay principally in August and September. The bloom was occurred only in 2017, being the first information of $\mathrm{C}$. tuberculata mass appearance in this area. We hypothesized that global warming phenomena could trigger the observed changes, and in this respect, long-term trends of sea surface temperature (SST) fluctuations were analysed. The scyphomedusae blooms coincided with high positive SST anomalies, noted in the last seven years for this area. To better understand the mechanisms underlying changes in their phenology and abundance, detailed studies on benthic stages in the Bay are essential.

Key words: jellyfish, blooms, phenology, sea surface temperature, Mediterranean Sea

\section{INTRODUCTION}

Climate studies of global warming and variation of precipitation over the last decades (LEVITUS et al., 2009; MARBÀ et al., 2015) have demonstrated a strong influence on changes in physiology and phenology of organisms, their spatial-temporal distribution, taxonomic composition of communities and the dynamics of the food web (POLOCZANSKA et al., 2013). In addition, excessive coastline modification has led to habitat loss affecting species richness and abundances (AIROLDI et al., 2008), while the proliferation of the artificial underwater structures may offer opportunities for some opportunistic species (DUARTE et al., 2013; VODOPIVEC et al., 2017).

Jellyfish are conspicuous members of plankton communities and have a prominent ecological role. While many jellyfish populations 
fluctuate with climatic cycles (LYNAM et al., 2004; PURCELL \& DECKER, 2005), recent evidence suggests that jellyfish may also be benefiting from human interactions with the oceans, and thus may be increasing globally (PURCELL et al. 2007; RICHARDSON et al. 2009; KOGOVŠEK et al., 2018). Increased jellyfish populations could strongly influence marine ecosystems and economy in many ways, as they compete with fish for prey (PURCELL \& ARAI, 2001), clog nets and sting (UYE, 2008; NASTAV et al., 2013; DE DONNO et al., 2014), affect fisheries (PALMIERI et al., 2014; CONLEY \& SUTHERLAND, 2015) and the tourist industry (GHERMANDI et al., 2015).

In the Mediterranean Sea many jellyfish species, both native and non-native reside, and some of them have been monitored for centuries while other were rarely studied (BROTZ \& PAULY, 2012; D'AMBRA \& MALEJ, 2015). In recent years, special attention has been paid to some scyphomedusae species which appear in large masses, i.e. form blooms. Their blooms were ubiquitous, but an increase of populations was noted in many areas, especially in coastal ecosystems (BOERO, 2013). In the Adriatic Sea, chronological notes of scyphomedusae outbreaks are related mainly to the northern region (AVIAN \& ROTTINI-SANDRINI, 1994; MALEJ, 2001; KOGOVŠEK et al., 2010) and along the Italian Adriatic coast (BOERO, 2013). The data for the middle and south Adriatic refers primarily to Pelagia noctiluca, which was relatively rare until 1977, and began blooming frequently in the early 1980 s (ZAVODNIK, 1987; BOERO, 2013). This jellyfish outbreak had a great impact on whole Adriatic ecology through the disturbance of the food web with the final consequence on fishing activities (BOERO, 2013). Another scyphozoan species was recorded for its short-term mass occurrence (26 August - 02 September 1998), the species Cotylorhiza tuberculata along the south Adriatic coast (BENOVIĆ \& LUČIĆ, 2001). Recently, in the southern and middle Adriatic scyphozoans mass occurrences have been rarely identified (LUČIĆ, D., unpublished data). The exception is the constant high abundance of Aurelia relicta (SCORRANO et al., 2016) in the salt lakes of Mljet Island, Croatia (BENOVIĆ et al., 2000; ALVAREZ COLOMBO et al., 2009, KOGOVŠEK et al., 2012).

In the Boka Kotorska Bay, despite the long tradition of zooplankton investigations (PESTORIĆ et al., 2017), there is generally very little information for gelatinous carnivores. LUČIĆ et al. (2012) recorded the first bloom of the ctenophore Bolinopsis vitrea in the Mediterranean (spring 2009), having a major impact on the planktonic food web structure. In addition, a bloom of hydromedusa Obelia spp (341 ind $\mathrm{m}^{-3}$ ) had also been described (PESTORIĆ et al., 2012). Among the scyphomedusan fauna, BABIĆ (1913) cites the finding of a rare species Drymonema dalmatinum, whose sightings were again reported from the area only after 90 years (MALEJ et al., 2014). VUKANIĆ (2006) notified the first record of one Chrysaora hysoscella specimen in the summer 2006. Beside these, there are no recorded data for other gelatinous species, although it is known that individuals of the genus Aurelia could be seen from December to May (MAČIĆ, personal communication).

After 2013, we have observed changes in scyphomedusan composition, phenology and abundance throughout the Boka Kotorska Bay. Thus, given the unavailability of published data, the principal objective of this work is to present the information of recent jellyfish events. We hypothesized that global warming phenomena, primarily the increase in sea surface temperature, could trigger the observed changes. In this respect, long-term trends of fluctuations and variations of sea surface temperature are analysed. Therefore, this study will attempt to establish the time series analytical framework that will contribute to understanding the trends of jellyfish appearance and abundance in the Boka Kotorska Bay.

\section{MATERIAL AND METHODS}

\section{Study area}

The Boka Kotorska Bay is a relatively large $\left(87 \mathrm{~km}^{2}\right)$ shallow semi-enclosed area, located in the south-eastern part of the Adriatic Sea (Fig. 1). The Bay comprises three basins: The KotorRisan Bay, the Tivat Bay and the Herceg Novi 


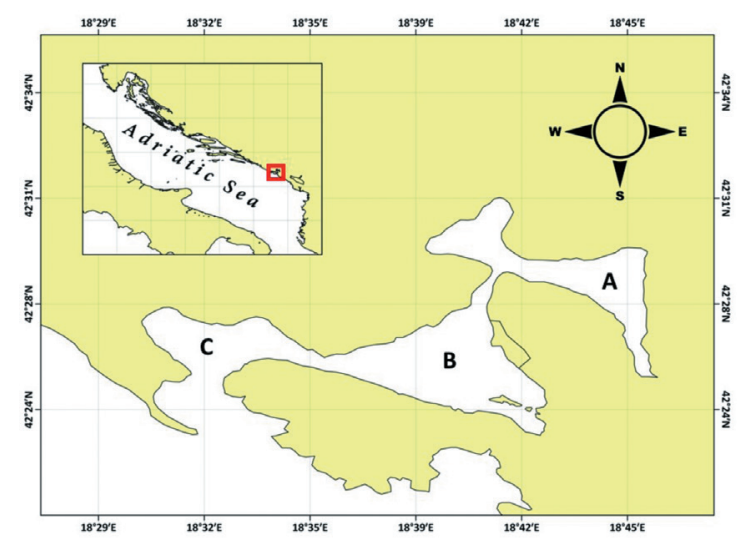

Fig. 1. (a) Position of the Boka Kotorska Bay in the Adriatic Sea. (b) Map of the Boka Kotorska Bay: A - Bay of Kotor-Risan; B-Bay of Tivat; C-Bay of Herceg Novi

Bay. Often referred to as a fjord owing to its dramatically steep mountain walls, it is in fact, a submerged river canyon. The whole area is greatly influenced by the large influx of fresh water from streams and submarine springs. The highest surface salinity oscillations occur in the shallower Kotor-Risan Bay (9.2 - 35.2), and the lowest in the Herceg Novi Bay (18,0 - 37.7) (MANDIĆ et al., 2017a). The water exchange with the southern Adriatic depends primarily on tidal variations with incoming currents near the bottom and outgoing currents on the surface. The specific geographical position and the combination of environmental factors create ecological conditions, which are different in many ways from those of the area outside the Bay. Based on the phytoplankton composition and abundance, the Bay is moderately eutrophic (DRAKULOVIĆ et al., 2017). At the same time, it is under pronounced pressures by tourism and related urban development (KNEŽEVIĆ \& PETOVIĆ, 2017).

\section{Seawater temperature}

Monthly and yearly averages of sea surface temperature (SST) from 1984 to 2017 were used as a climate proxy of the Boka Kotorska Bay. Data were provided by the Montenegrin Meteorological and Hydrological Service, supplemented with data measured by the Institute's staff with various hydrographic probes. Data for the Kotor Bay and the Herceg Novi Bay were analyzed and integrated into a single database. The SST for the Tivat Bay was not analyzed due to the small number of available data. In addition, during the blooms of Discomedusa lobata vertical profile of temperature and salinity were obtained by in situ measurements with a HQ40d Multi-Parameter Digital Meter.

The inter-annual SST trend is shown by a linear regression model. Using the least squares method, the straight line of the equation was defined which had the slightest deviation from the empirical values. SST data were presented as yearly and seasonal anomalies, i.e. departures from a long-term (1984 - 2017) average. Yearly seasonal values were determined as an average of January - March values for winter, April June for spring, July - September for summer, and October-December for autumn.

\section{Observations and estimation of schyphomedusae abundance}

Continuous monitoring of the scyphomedusae occurrence in the Boka Kotorska Bay started in 2013. Monitoring was conducted monthly by visual observations of scientists of the Institute of Marine Biology (Kotor, Montenegro) from the shore, with a video camera operated remotely from a research vessel and during dives. Additional information was obtained from fishermen's, local sailors and reliable sources on the basis of validated reports organized through the actions of "Citizen Science".

A semi-quantitative time series (2013 - 2017) of medusan occurrence has been constructed from field observations. A value between 0 and 3 was attributed to each month according to the following criteria: when medusae were not observed, a 0 value was attributed to that month; a value of 1 corresponded to the sporadic events of individual organisms noted; 2 was attributed when medusae were numerous and frequently observed within the specific month; and 3 represented the months when numerous medusae were frequently observed, and at least one blooming event was recorded.

Specimens of the genus Aurelia are determined as Aurelia spp., due to the fact that 
genetic analysis revealed several cryptic species of previously ubiquitous Aurelia aurita (DAWSON \& JACOBS, 2001). SCORRANO et al. (2016) recently identified Aurelia coerulea von Lendenfeld, 1884 and Aurelia solida Browne, 1905 as the two species established in the coastal areas across the Mediterranean Sea. For the purpose of this study, no phylogenetic analysis was performed to clarify the identity of the specimens from the investigated area. In addition, our dataset consists of data collected before the publication of SCORRANO et al., (2016); therefore, we denoted Aurelia specimens as Aurelia spp.

Biometric measurements of jellyfish were performed when they were found in larger numbers. Specimens were carefully hand-collected and stored in a plastic bucket in a shaded place. Bell diameters were measured to the nearest 1 $\mathrm{mm}$ on freshly collected medusae flattened on a glass plate with the oral side facing up. Gut content of Discomedusa lobata were checked by examining the oral arms and radial canals of 60 specimens (bell diameter rang $3-8 \mathrm{~cm}$ ) using an Olympus SZX-9 stereomicroscope.

\section{RESULTS}

\section{Sea surface temperature}

Considering the total analyzed period (1984 - 2017), there was an increasing trend of SST of $0.48^{\circ} \mathrm{C}$ per decade (Fig. 2). Inter-annual changes of SST showed marked variations and predominant negative anomalies over the $1980 \mathrm{~s}$ to the mid of 1990s (Fig. 3, top). From the end of 1990 s to 2010 , a high inter-annual variation was noted with minor deviations from the average. The warming has particularly intensified since 2010 and followed by seven warm years, six being more than $0.5{ }^{\circ} \mathrm{C}$ warmer then the longterm average (Fig 3.). During the later period, warming was accounted due to the higher than average SST in all seasons, particularly in spring with 11 consecutive years $(2007-2017)$ of SST higher than the long-term average: $>0,5$ ${ }^{\circ} \mathrm{C}$ in all years except $2013\left(0.24^{\circ} \mathrm{C}\right)$ and 2014 $\left(0.45^{\circ} \mathrm{C}\right)$. According to our data, 2015 was an exceptionally warmer year with annual mean of

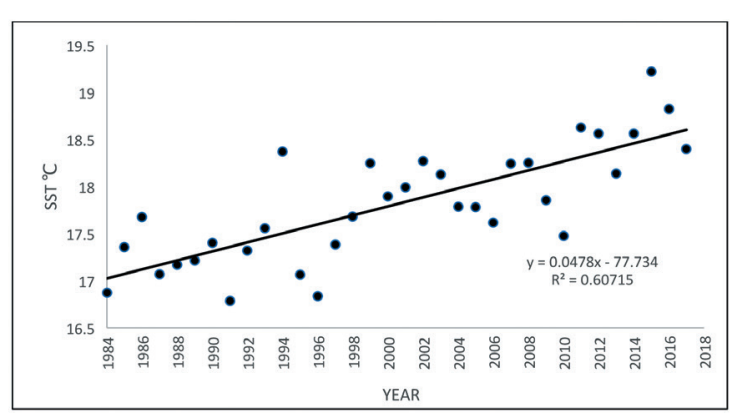

Fig. 2. SST linear trend for 1980-2017

$1.41^{\circ} \mathrm{C}$ above the long-term average due to high summer and autumn SST of 2.19 and $1.68^{\circ} \mathrm{C}$ above the average, respectively.

\section{Scyphomedusae}

Six species of scyphomedusae were recorded in the Boka Kotorska Bay from 2013 to 2017: Aurelia spp. (Linnaeus, 1758), Chrysaora hysoscella (Linnaeus, 1767), Cotylorhiza tuberculata (Macri, 1778), Discomedusa lobata Claus, 1877, Drymonema dalmatinum (Haeckel, 1880) and Rhizostoma pulmo (Macri, 1778). Among them, C. hysoscella, D. lobata, and C. tuberculata formed blooms.

\section{Bloom forming species}

Chrysaora hysoscella was present in the Boka Kotorska Bay from 2014 to 2017 (Fig. 4). It was observed from February to August, but was most common in April and May with 40 and $20 \%$ of total observations (170), respectively (Fig. 5). Mass occurrence of this jellyfish was recorded in 2014, 2015 and 2017 in the whole study area. An especially extended bloom of 14 days occurred in 2015. In this year, specimens were observed in the water column of the Bay for 58 consecutive days (Fig. 6). The smallest number of continuous observations of only 10 consecutive days was noted in 2016 during the only non-bloom year of the investigated period. Individual bell diameters ranged between 6 (February) and 28 $\mathrm{cm}$ (May, 2017), on average $14.4 \pm 4.5 \mathrm{~cm}$ $(\mathrm{N}=121)$. The highest frequency of medusae 

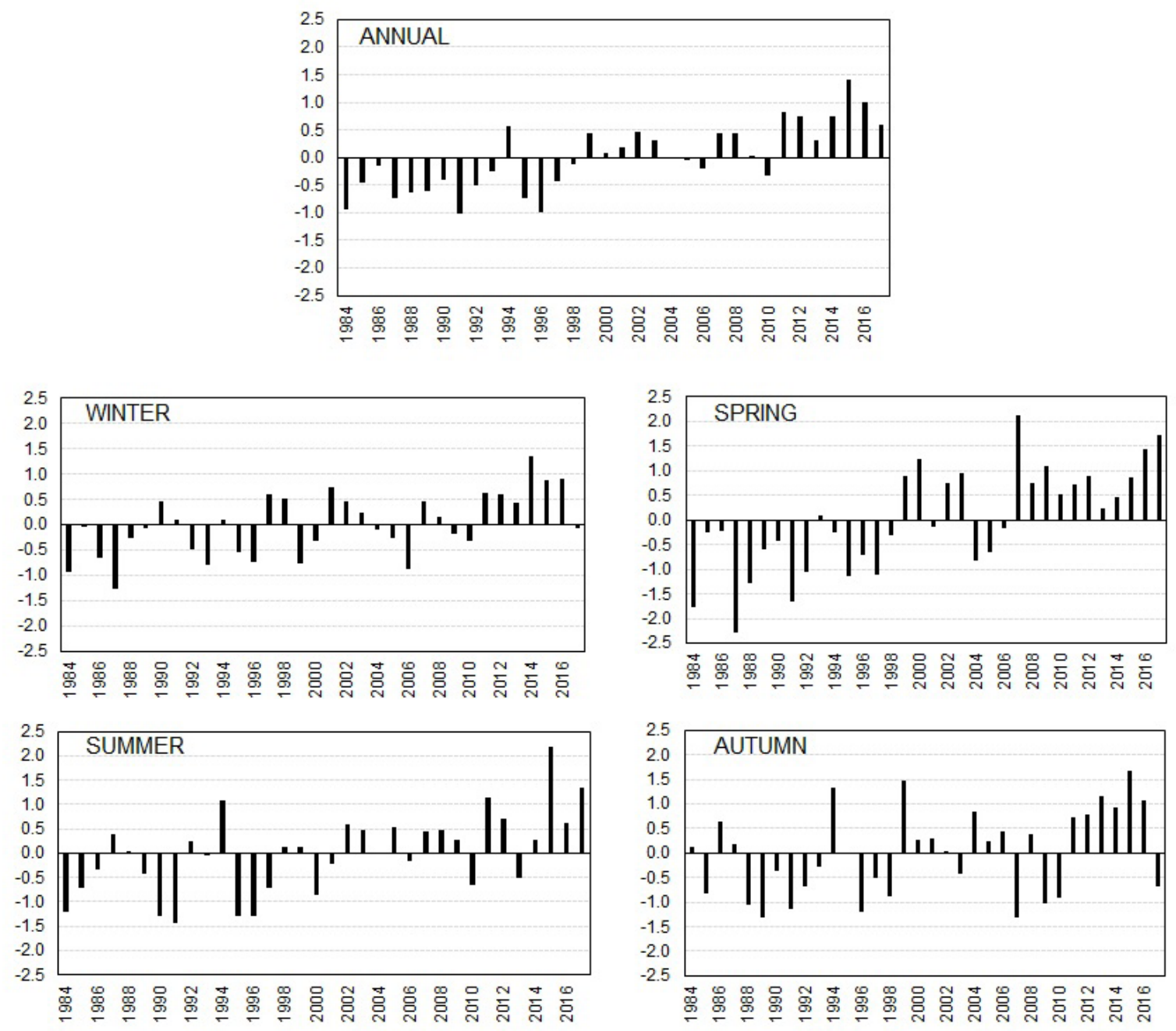

Fig, 3. Long-term yearly and seasonal sea surface temperature anomalies in the Boka Kotorska Bay

bell diameters collected in the Boka Kotorska Bay, were in the range of $16-18 \mathrm{~cm}$ (Fig. 7).

The first reliable record of Discomedusa lobata in the Boka Kotorska Bay was noted in 2013 when specimens were found sporadically from early March to June in the inner area of the Bay (Fig. 4). The first bloom with estimated density at 100 individuals per $10 \mathrm{~m}^{2}$, was noted in April 2014, and a similar one in mid-May. The latter lasted two days after which no individuals were observed. High numbers (10 ind. per $10 \mathrm{~m}^{2}$ ) were present for over eight days in February 2015, after which individuals were found only sporadically until end of March, when an extremely dense bloom occurred in a shallow part of the Bay that is influenced by spring water (Fig. 8). Water column temperature during blooms ranged from 13.5 to $19.1{ }^{\circ} \mathrm{C}$. Salinity generally was low, ranging between 8.5 and 25.5. Bell diameters $(\mathrm{N}=160)$ ranged from 2.1 (March 2015) to $9.2 \mathrm{~cm}$ (March 2013), with the highest frequency of medusae size between 4 and $5 \mathrm{~cm}$ (Fig. 9). Specimens with bell size larger than $4 \mathrm{~cm}$ had developed gonads. Sex was not determined. During March 2013, exclusively the salp Thalia democratica was found as prey (10 medusae inspected), while gastric cavities were empty during other bloom events (50 medusae inspected).

Cothyloriza tuberculata, a summer species, was rarely seen in the Bay until 2017. It was 
Chrysaora hysoscella

\begin{tabular}{|l|l|l|l|l|l|}
\hline January & & & & & \\
\hline February & & & & & \\
\hline March & & & & & \\
\hline April & & & & & \\
\hline May & & & & & \\
\hline June & & & & & \\
\hline July & & & & & \\
\hline August & & & & & \\
\hline September & & & & & \\
\hline October & & & & & \\
\hline November & & & & & \\
\hline December & & & & & \\
\hline
\end{tabular}

\section{Discomedusa lobata}

\begin{tabular}{|l|l|l|l|l|l|}
\hline January & & & & & \\
\hline February & & & & & \\
\hline March & & & & & \\
\hline April & & & & & \\
\hline May & & & & & \\
\hline June & & & & & \\
\hline July & & & & & \\
\hline August & & & & & \\
\hline September & & & & & \\
\hline October & & & & & \\
\hline November & & & & & \\
\hline December & & & & & \\
\hline
\end{tabular}

Cothyloriza tuberculata

\begin{tabular}{|l|l|l|l|l|l|}
\hline January & & & & & \\
\hline February & & & & & \\
\hline March & & & & & \\
\hline April & & & & & \\
\hline May & & & & & \\
\hline June & & & & & \\
\hline July & & & & & \\
\hline August & & & & & \\
\hline September & & & & & \\
\hline October & & & & & \\
\hline November & & & & & \\
\hline December & & & & & \\
\hline
\end{tabular}

Fig. 4. Temporal distribution of bloom-forming jellyfish in the Boka Kotorska Bay from 2013 to 2017. Colors indicate the relative abundance of jellyfish: blue = sporadic events of individual organisms; yellow= medusae were numerous and frequently observed; red= larger aggregations were frequently observed, as well as blooming events

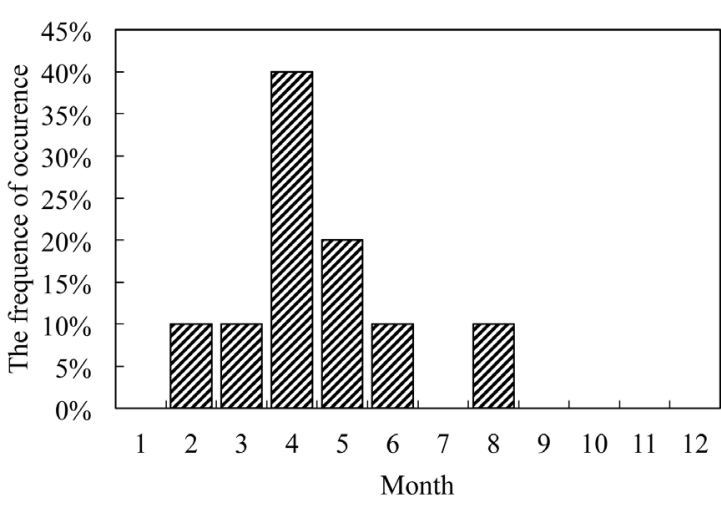

Fig. 5. Monthly frequency of occurrence of Chrysaora hysoscella in the Boka Kotorska Bay from 2013 to 2017

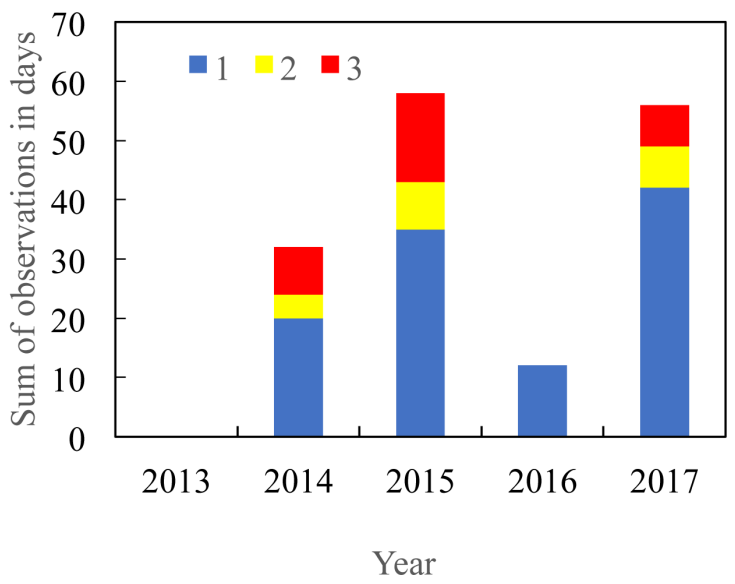

Fig. 6. Annual presence of Chrysaora hysoscella in the Boka Kotorska Bay by days $(1=$ individual; 2 = numerous; 3 = bloom)

observed only sporadically, predominantly from August to September in the years between 2013 and 2016 (Fig. 4). However, in 2017 large outbreaks of $C$. tuberculata were recorded in the whole Boka Kotorska Bay. It was continuously present for 60 days from 27 of July to the 25th of September, and in masses from August 09 to September 05. Bell diameters for 57 specimens measured during bloom ranged between $4 \mathrm{~cm}$ and $40 \mathrm{~cm}$. Most of them were between $15 \mathrm{~cm}$ and $30 \mathrm{~cm}$.

\section{Non-bloom forming species}

Since 2013, Aurelia ssp. specimens were rarely noticed (Fig. 10). The higher relative abundance was recorded at the end of May 2015 , with the duration of its presence of nine 


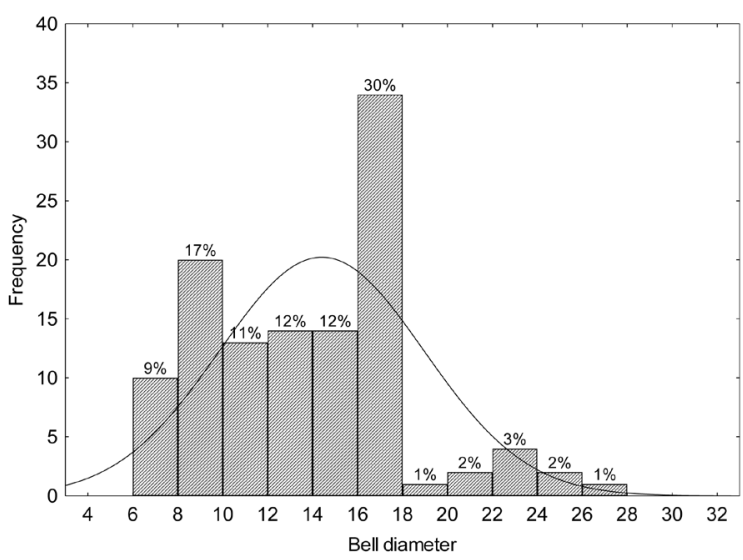

Fig.7. Bell size-frequency distribution of Chrysaora hysoscella in the Boka Kotorska Bay $(N=121)$

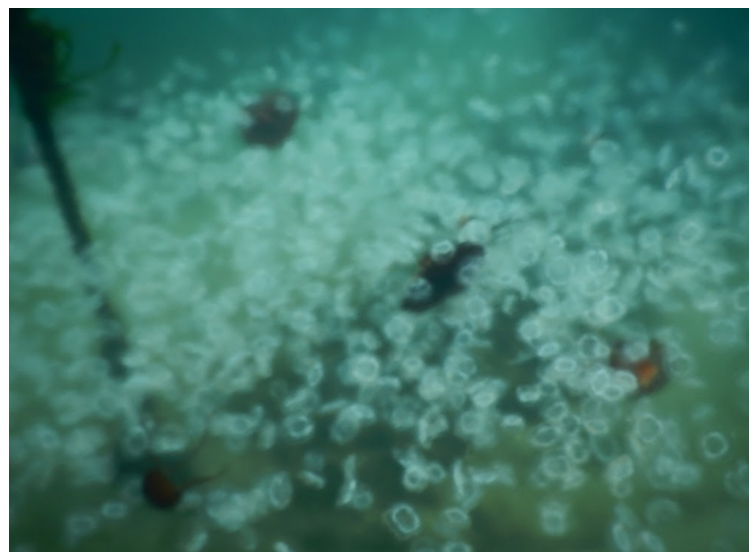

Fig. 8. Discomedusa lobata bloom close to the river spring, 27 March 2015 (Foto: V. Mačič)

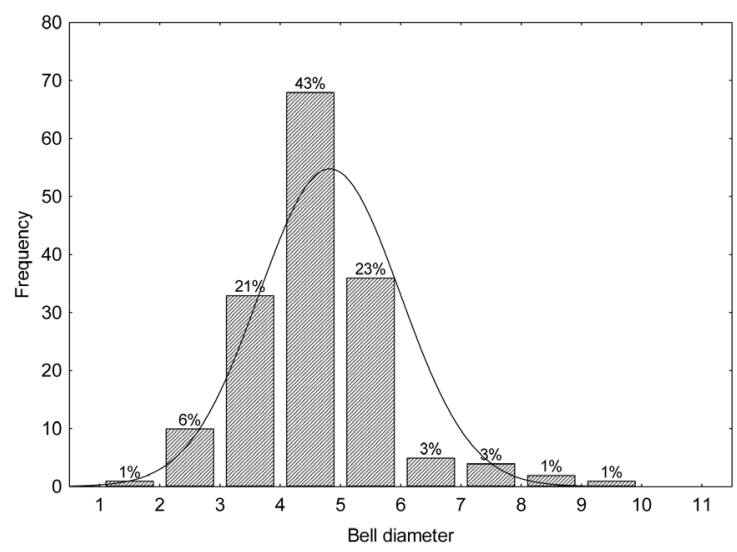

Fig. 9. Bell size-frequency distribution of Discomedusa lobata in the Boka Kotorska Bay $(N=160)$

consecutive days. Aurelia spp. medusae were more frequently observed in 2017, when were randomly found from February to July.
Drymonema dalmatinum was noted in a small number of specimens in June and August of 2014, and from April to June 2017, what is the longest known permanent retention in the Adriatic Sea (Fig. 10). Medusae were found mainly at the surface of the water column oriented with the bell upside down, or less often when the bell is vertically laid with long tentacles spreading behind it. Bell diameters varied from $15 \mathrm{~cm}$ to $60 \mathrm{~cm}(\mathrm{~N}=7)$, measured in May and June 2017, respectively. The bell color of the larger specimens was darker, and of the smaller specimens was milky-transparent.

Rhizostoma pulmo were rare and the less abundant Scyphozoa species in the Boka Kotorska Bay, periodically noted from June to October. In a slightly higher number of individuals was recorded only in August 2017 (Fig. 10).

\section{DISCUSSION}

Six scyphomedusae species were recorded in the Boka Kotorska Bay during 2013 - 2017: Aurelia spp, Chrysaora hysoscella, Cotylorhiza tuberculata, Discomedusa lobata, Drymonema dalmatinum and Rhizostoma pulmo. Aurelia spp., D dalmatinum and R. pulmo were observed sporadically and represented only by few individuals, except for short period of medusae aggregations in 2015 and 2017 for Aurelia and $R$. pulmo, respectively. This is in contrast with reports from many coastal areas in the Mediterranean Sea, where extended episodes of blooming events of the two species are common (KOGOVŠEK et al., 2010; FUENTES et al., 2011; MALEJ et al., 2012). In contrast, D. dalmatinum, a rhizostomid species that was very rarely recorded in the Mediterranean Sea, has become increasingly common in the Bay. In fact, in 2017 medusae were present for three consecutive months (April-June), which is the longest known permanent retention in the Adriatic Sea.

On the other hand, $C$. hysoscella and $D$. lobata were very common in the Bay, along with C. tuberculata in 2017. During winter and spring, $C$. hysoscella and D. lobata were often numerous in the water column, forming dense aggregations in March and May, and February 
to May, respectively. Our description of the $D$. lobata blooms is actually the first known records for this species. D. lobata was first described by CLAUS (1877) from the specimen(s) collected in the Gulf of Trieste, the northern Adriatic Sea. There are occasional reports from the western Mediterranean Sea (RANSON, 1945; MADIN, 1991; PAGES et al., 1992: GUERRERO, 2018), the western coast of Africa (PAGES et al., 1992) and the English Channel (see RUSSELL, 1970). Despite being known since the 19th century, there is very little information about biology of this species. Since 1914, when it was first described, it was not mentioned for the Gulf of Trieste until the period 1981-1985 (AVIAN, 1992). After that, it was recorded only in 2011 in the Marmara Sea, Turkey, and again and in high abundance two years later (ISINIBILIR et al., 2015). Therefore, our results and findings of ISINIBILIR et al. (2015) represent the first published data for this jellyfish after 25 years in the Mediterranean, and the first record for the Adriatic outside its northern part. Mean sizes of the D. lobata bells in the Bay are consistent with the results of AVIAN (1992), measuring mostly between 2 and $8 \mathrm{~cm}$, while the maximum size of up to $15 \mathrm{~cm}$ reported for the northern Adriatic Sea were not recorded in the Boka Kotorska Bay. AVIAN (1992) observed that adult specimens resided outside the Gulf of Trieste and linked it to the possibility of its reproduction area being in the open sea. Our finding was the opposite: a mass of sexually mature specimens was recorded just inshore in direct contact with fresh water inlet, which points to the importance of low temperature and salinity for reproduction of this medusa. In any case, our estimation of abundance included the highest known values reported for $D$. lobata.

The compass jellyfish $C$. hysoscella in the Boka Kotorska Bay was first reported for 2006 (VUKANIĆ, 2006) and it was regularly present from 2014 on, frequently forming blooms in spring. Despite being native to the Mediterranean Sea, there is no sufficient literature information about $C$. hysoscella distribution and abundance to enable us comparing the results with the observations across the basins of the Mediterranean Sea. In the northern Adriatic, it was first reported for 1874 and was regularly observed since then (KOGOVŠEK et al., 2010). Since 2003, C. hysoscella was present from February to July, but it rarely formed blooms (KOGOVŠEK, unpublished data). The seasonal dynamic of $C$. hysoscella medusae in the Boka Kotorska Bay is therefore consistent with the observations from the northern Adriatic Sea. To our best knowledge, there are only two documented short-time blooms for this species in the northern Adriatic: June 1910 (BABIĆ, 1913) and spring 1989 (DEL NEGRO et al., 1992). Outside the Adriatic basin, higher numbers were noted in the Marmara Sea in May (İşINIBILIR \& YILMAZ, 2016). The mean abundance of $C$. hysoscella was increased from 2001 to 2009 in this area, but then it sharply decreased in 2010 and since then it was sporadically observed (ISTINIBILIR \& YILMAZ, 2016). Therefore, our data present important information on the seasonal dynamic of this species and the record of the most prolonged outbreaks of this species in the Adriatic, as well as in the Mediterranean Sea.

Cotylorhiza tuberculata was observed sporadically, principally from August to September in the years between 2013 and 2016. However, the bloom was established only in 2017 , being the first official record of $C$. tuberculata mass appearance in this area. In the coastal part of the southern Adriatic Sea, outside the Boka Kotorska Bay, only two individuals were recorded in August 2015 (for 2013 - 2017 period), while in middle and in the northern area of the Adriatic Sea it was frequent and abundant during the same period (LUČIĆ, pers. comm.). C. tuberculata is the warm-water jellyfish which is known to form blooms in the whole Mediterranean Sea; yet, the published information on this species is very scarce (KIKINGER, 1992; KOGOVŠEK et al., 2010; RUIZ et al., 2012; ASTORGA et al., 2012). Based on limited data published in previous reports, we concluded that medusae seasonal dynamic and the measured size ranges are consistent with previously published data from two Mediterranean regions, the Ionian Sea, Greece, and the Mar Menor, Spain (KIKINGER, 1992; RUIZ et al., 2012).

The causes of jellyfish blooms are manifold (BOERO et al., 2008), and several are linked to local 
conditions that favor episodic and rapid increases of population sizes of many species (DUARTE $e t$ al., 2013), and specific organismal traits (DAWSON \& HAMNER, 2009). Since the phenomenon has become global, the causes are seen in the aspect of global changes. Generally, increases in jellyfish populations are hypothesized to be caused by the synchronic forcing of climate change and the anthropogenic impacts on the marine environment. These drivers include global warming, eutrophication, overfishing, mariculture and coastal development (MILLS, 2001; PURCELL et al., 2007; RICHARDSON et al., 2009; DUARTE et al., 2013, VODOPIVEC et al., 2017). Most Scyphozoans are metagenetic with alternation of a perennial benthic polyp that reproduce asexually, and sexually reproducing planktonic medusa stage. In perturbed ecosystems, such life traits/jellyfish physio-ecological properties enable them to tolerate some environmental stressors better than other organisms, thus facilitating the proliferation of one or both life stages that may lead to harmful jellyfish blooms. In this respect, many scientists consider sea temperature rise as one of the most important agents (LYNAM et al., 2004; BOERO et al., 2016), affecting all life stages. In temperate environments, temperature rise has been shown to favor asexual reproduction of polyp population (HAN \& UYE, 2010; PURCELL et al., 2012; HUBOT et al., 2017) or trigger strobilation of warmer species (PRIETO et al., 2010; RUIZ et al., 2012; LUCAS et al., 2012; ASTORGA et al., 2012), while for medusae warmer conditions lead to increased growth rate (WIDMER, 2005; VAN WALRAVEN et al., 2015) and eggs production (PURCELL \& DECKER, 2005). Our results of SST variations in the Boka Kotorska Bay clearly showed an overall increasing trend and positive temperature anomalies since 2011. In addition, analyses have shown a sharp increase in average values in all seasons compared to years before 2011 (Fig. 3). These results are concomitant with data obtained from the long-term (1959 - 2015) analysis of mid-Adriatic (GRBEC et al. 2018). GRBEC et al. (2018) emphasized that the SST warming was noticeable after 1980 and has particularly intensified since 2008, with trends as high as $1.56{ }^{\circ} \mathrm{C} /$ decade. For the northern Adriatic, one of the most elaborated areas involved in jellyfish outbreaks in the Mediterranean, KOGOVŠEK et al. (2018) points out a substantial increase of jellyfish since 1980s and in particular from 2000 to the present (KOGOVŠEK et al., 2010; MALEJ et al., 2012), concomitant with the changes in climate. In the Boka Kotorska Bay, the scyphomedusae blooms coincided with high positive temperature anomalies. The 2015 was a particularly warm year in which D. lobata and C. hysoscella were observed earlier in the season compared to other years (Fig. 4). Mild winter with SST of $0.89{ }^{\circ} \mathrm{C}$ above the long-term average may have stimulated faster ephyrae development and medusae growth rate, making them easier to detect in the water column by our visual census. On the other hand, extremely warm summer may have caused senescence and abrupt collapse of the medusae population (GATZ et al., 1973) earlier in the season. Common patterns in interannual fluctuations in seasonality and abundance, allow us to speculate that similar forcing are driving the population dynamic of both species. In addition, $C$. hysoscella and D. lobata formed dense aggregations and blooms in 2015 (and the former in 2017), in the year with high Aurelia spp. densities. Intraguild predation on Aurelia spp. may provide valuable energy to fuel the numerous populations of the two sympatric species. Both, C. hysoscella and D. dalmatinum are voracious predators on gelatinous zooplankton (LARSON, 1987; PURCELL, 1991; KINOSHITA et al, 2006). In fact, Aurelia medusae were observed more frequently in the Boka Kotorska Bay prior our investigations (personal announcements of residents). Thus, competition, but mostly predation by co-occurring gelatinous species may be important driver/control of Aurelia spp. population in the Bay. Likewise, we speculate that the ctenophore Bolinopsis vitrea, that was blooming in spring 2009 and was often observed until 2014 (LUČIĆ et al., 2012), almost disappeared in last years. On the other hand, the warm-water species, C. tuberculata may be benefiting from the warming sea: mild winters increase the survival of the polyps (PURCELL et al., 2012), while earlier increase in SST in spring above $21^{\circ} \mathrm{C}$ triggers strobilation earlier (KIKINGER, 
1991; PURCELL et al., 2012), and high spring and summer temperatures promote medusae growth. Indeed, extremely high spring SST in 2017 lead to earlier detection of $C$. tuberculata medusae by visual census (July compared to August in all previous years investigated). However, unusually cold autumn may be the reason for an abrupt collapse of blooming population in that year.

In addition to an increasing trend in SST, the consistency of the polyp reservoir is the premise for the onset of the blooms for the species with a benthic stage (DUARTE et al., 2013; LUCAS et al., 2012). Due to their size, the locations of polyp populations in their natural environment are very rarely identified. In the Adriatic Sea, only Aurelia spp. polyp colonies have been located and identified (DI CAMILIO et al., 2010; MALEJ et al., 2012). Currently, there are no data on the presence, the distribution and the abundance of scyphistomae in the Boka Kotorska Bay. However, due to the continuous and abundant presence of medusae stages of certain species in the Bay (juvenile and mature), and the fact that the jellyfish blooming was very rarely observed in the southern Adriatic Sea outside the Bay (LUČIĆ \& PESTORIĆ, pers. comm.), speculative conclusions can be made about the possibility of established polyp populations in the area. Therefore, further investigations are needed to untangle the role of polyps in medusa blooming dynamic under the patterns of change detected in the marine

\section{CONCLUSIONS}

In this study we provided the first valuable insight into the scyphomedusan phenology and variations in abundance in the Boka Kotorska Bay. Based on our semi-quantitative dataset of jellyfish occurrence we concluded that the jellyfish in the study area have become more frequent and abundant after 2013. This increase was concomitant with the impulsive sea-surface warming detected for the region during the last decades. Similar patterns have been previously reported from several regions of the Mediterranean Sea (e.g. KOGOVŠEK et al., 2010; BROTZ et al., 2012; BOERO, 2013) and the authors proposed climate change as one of the important drivers. Increasing trend in sea-water temperature may have direct or indirect effect on both, pelagic and benthic stages of scyphozoan species. The current research was focused only on the medusa stage, since the locations of the scyphistoma colonies in the Bay have not been identified yet. However, due to regular observations of juvenile and mature medusae in the Bay, and rare sighting or even their absence along the south Adriatic coast outside the Bay during the blooming events, we speculate that the six species established their population in the study area. Recent rapid artificial activity in the Bay through construction of docks, wharfs, marinas and sea walls (KNEŽEVIĆ \& PETOVIĆ, 2017), as well as an increase in the capacity of shellfish farming (MANDIĆ et al., 2017b) may have provided additional habitat for polyps that contributed to the enhancement of jellyfish population size (MALEJ et al., 2012; DUARTE et al., 2013). A steady increase in artificial marine structures may then have acted additively and synergistically with climate change, creating environment in which opportunistic jellyfish may thrive. Thus, to better understand the complex mechanisms underlying changes in phenology and abundance of the scyphozoan in the Bay, detailed studies on benthic stage are essential.

\section{ACKNOWLEDGMENTS}

CROATIAN SCIENCE FOUNDATION funded this study under the project IP-2014-09-2945, and MINISTRY OF SCIENCE, MONTENEGRO, under the projects $01-620$ and 2011-2014. SST data was obtained from projects funded by MINISTRY OF AGRICULTURE AND RURAL DEVELOPMENT, MONTENEGRO, AGENCY FOR NATURE AND ENVIRONMENT PROTECTION, MONTENEGRO AND INSTITUTE OF HYDROMETEOROLOGY AND SEISMOLOGY OF MONTENEGRO. Authors thank all the volunteers that shared their jellyfish sightings. 


\section{REFERENCES}

AIROLDI, L., D. BALATA, \& M. W. BECK. 2008. The gray zone: relationships between habitat loss and marine diversity and their applications in conservation. J. Exp. Mar. Biol. Ecol., 366: $8-15$.

ALVAREZ COLOMBO, G., A. BENOVIĆ, A. MALEJ, D. LUČIĆ, T. MAKOVEC, V. ONOFRI, M. ACHA, A. MADIROLAS \& H. MIANZAN. 2009. Acoustic survey of a jellyfish-dominated ecosystem (Mljet Island, Croatia). Hydrobiologia, 616: 99-111.

ASTORGA, D., J. RUIZ \& L. PRIETO. 2012. Ecological aspects of early life stages of Cotylorhiza tuberculata (Scyphozoa: Rhizostomeae) affecting its pelagic population success. Hydrobiologia, 690: 141-155.

AVIAN, M. 1992. Occurrence of Discomedusa lobata (Cnidaria: Scyphozoa) in the Adriatic with notes on morphology. Oebalia, 17: 271274.

AVIAN, M. \& L. ROTTINI SANDRINI. 1994. History of schyphomedusae in the Adriatic Sea. Bolletino della Societa Adriatica di Science Naturali in Trieste, 1: 5-12.

BABIĆ, K. 1913. Planktonski celenterati iz Jadranskog mora. JAZU, 200: 186-202.

BENOVIĆ, A. \& D. LUČIĆ. 2001. Jellyfish outbreak: natural cycle or stress response effect. In: F. Briand (Editor). Gelatinous zooplankton outbreaks: theory and practice. CIESM Workshop Series, 14: 59-62.

BENOVIĆ, A., D. LUČIĆ, V. ONOFRI, M. PEHARDA, M. CARIĆ, N. JASPRICA, \& S. BOBANOVIĆĆOLIĆ. 2000. Ecological characteristic of the Mljet Island seawater lakes (South Adriatic Sea) with special reference to their resident populations of medusae. Sci. Mar., 64: 197206.

BOERO, F. 2013. Review of jellyfish blooms in the Mediterranean and Black Sea. Studies and Reviews. General Fisheries Commission for the Mediterranean. No. 92. Rome, FAO 2013., 53 pp.

BOERO, F., J. BOUILLION, C. GRAVILI, M. P. MIGLIETTA, T. R. PARSONS \& S. PIRAINO. 2008. Gelatinous plankton: irregularities rule the world (sometimes). Mar. Ecol. Prog. Serr., 356: 299-310.

BOERO, F., L. BROTZ, M. J. GIBBONS, S. PIRAINO \& S. ZAMPARDI, 2016. 3.10 Impacts and effects of ocean warming on jellyfish. In: D. Laffoley, D. \& J. M. BAXTER (Editors). Explaining ocean warming: Causes, scale, effects and consequences. Gland, Switzerland, IUCN, 213-237.

BROTZ, L. \& D. PAULY. 2012. Jellyfish populations in the Mediterranean Sea. Acta Adriat., 53: 213-232.

BROTZ, L., W. W. CHEUNG, K. KLEISNER, E. PAKHOMOV \& D. PAULY. 2012. Increasing jellyfish populations: trends in large marine ecosystems. Hydrobiologia 690: 3-20.

CLAUS, C. 1887. Studien über Polypen und Quallen der Adria. Denkschr. Akad. Wiss. Wien, 38: 1-64.

CONLEY, K.R. \& K. R. SUTHERLAND. 2015. Commercial fishers' perceptions of jellyfish interference in the Northern California Current. ICES J. Mar. Sci., 72: 1565-1575.

D'AMBRA, I. \& A. MALEJ. 2015. Scyphomedusae of the Mediterranean: State of the Art and Future Perspectives. Central Nervous System Agents in Medicinal Chemistry, 2015, 15, 81-94.

DAWSON, M. N. \& D. K. JACOBS. 2001. Molecular evidence for cryptic species of Aurelia aurita (Cnidaria, Scyphozoa). Biol. Bull., 200: 92-96.

DAWSON, M. N. \& W. M. HAMNER. 2009. A character basedanalysis of the evolution of jellyfish blooms: adaptation and exaptation. Hydrobiologia, 616: 193-215.

DEL NEGRO, P., F. KOKELJ, A. TUBARO \& R. DELLA LOGGIA. 1992. Chrysaora hysoscella in the Gulf of Trieste: presence, evolution and cutaneous toxicity in man. Sci. Total Environ., (Suppl): 427-430.

DE DONNO, A., A. IDOLO, F. BAGORDO, T. GRASSI, A. LEOMANNI, F. SERIO, M. GUIDP, M. CANITANO, S. ZAMPARDI, F. BOERO \& S. PIRAINO. 2014. Impact of stinging jellyfish proliferations along south Italian coasts: human health 
hazards, treatment and social costs. Int. J. Environ. Res. Public Health, 11: 2488-2503. DRAKULOVIĆ, D., B. PESTORIĆ, R. KRAUS, S. LJUBOMIR \& S. KRIVOKAPIĆ. 2017. Phytoplankton community and trophic state in Boka Kotorska Bay. In: A. Joksimović et al. (Editors), The Boka Kotorska Bay Environment. Hdb. Env. Chem., 54: 169-201. Springer International Publishing Switzerland, DOI 10.1007/698_2016_30.

DUARTE, C.M., K.A. PITT, C. H. LUCAS, J. E. PURCELL, S. UYE, K. ROBINSON, L. BROTZ, M. B. DECKER, K. R. SUTHERLAND, A. MALEJ, L. MADIN, H. MIANZAN, J. M. GILI, V. FUENTES, D. ATIENZA, F. PAGES, D. BREITBURG, I. MALEK, W. M. GRAHAM, \& R. H. CONDON. 2013. Is global ocean sprawl a cause of jellyfish blooms? Front. Ecol. Environ. 11: 91-97, doi:10.1890/110246.

FUENTES, V., I. STRAEHLER-POHL, D. ATIENZA, I. FRANCO, U. TILVES, M. GENTILE, M. \& A. ACEVEDO. 2011. Life cycle of the jellyfish Rhizostoma pulmo (Scyphozoa: Rhizostomeae) and its distribution, seasonality and inter-annual variability along the Catalan coast and the Mar Menor (Spain, NW Mediterranean). Mar. Biol., 158: 2247-2266.

GATZ, A. J., V. S. KENNEDY \& J. A. MIHURSKY. 1973. Effects of temperature on activity and mortality of the scyphozoan medusa Chrysaora quinquecirrha. Chesapeake Sci., 14: 171180.

GHERMANDI, A., B. GALIL, J. GOWDY, \& P. A. L. D. NUNES. 2015. Jellyfish outbreak impacts on recreation in the Mediterranean Sea: welfare estimates from a socioeconomic pilot survey in Israel. Ecosyst. Serv., 11: 140-147.

GRBEC, B., F. MATIĆ, G. BEG PAKLAR, M. MOROVIĆ, R. POPOVIĆ \& I. VILIBIĆ. 2018. Long-term trends, variability and extremes of in situ sea surface temperature measured along the eastern Adriatic coast and its relationship to hemispheric processes. Pure Appl. Geophys., https://doi.org/10.1007/s00024-018-1793-1.

GUERRERO, E., J.M. GILLI, J. GRINYÓ, V. RAYA \& A. SABATÉS. 2018. Long-term changes in the planktonic cnidarian community in a mesoscale area of the NW Mediterranean.
HAN, C. \& S. UYE. 2010. Combined effects of food supply and temperature on asexual reproduction and somatic growth of polyps of the common jellyfish Aurelia aurita. Plankton Benthos Res., 5: 98-105.

HUBOT, N., C.H. LUCAS \& S. PIRAINO. 2017. Environmental control of asexual reproduction and somatic growth of Aurelia spp. (Cnidaria, Scyphozoa) polyps from the Adriatic Sea. PLoS ONE 12(6): e0178482. https://doi. org/10.1371/ journal. pone. 0178482

ISINIBILIR, M., I. \& N. YILMAZ. 2016. Jellyfish species in the Sea of Marmara. In: Çağatay, Ö. E., N. M. Balkis, N. Balkis, N. Öztük \& B. Öztük (Editors). The Sea Marmara; Marine Biodiversity, Fisheries, Conversation and Governance. Turkish Marine Research Foundation, 390-400.

ISINIBILIR, M., I. N. YILMAZ \& N. DEMIREL. 2015. New records of the jellyfish species in the Marmara Sea. Ital. J. Zool., 82: 425-429.

KIKINGER, R. 1992. Cotylorhiza tuberculata (Cnidaria: Scyphozoa) - life history of a stationary population. P.S.Z.N.I: Mar. Ecol., 4: 333-362.

KINOSHITA, J. J. HIROMI \& Y. YAMADA. 2006. Abundance and Biomass of scyphomedusae, Aurelia aurita and Chrysaora melanaster, and ctenophora, Bolinopsis mikado, with Estimates of Their Feeding Impact on Zooplankton in Tokyo Bay, Japan. J. Oceanogr., 62: 607-615

KNEŽEVIĆ, J. \& S. PETOVIĆ. 2017. Integrated coastal zone management in Boka Kotorska Bay. In: A. Joksimović et al. (Editors), The Boka Kotorska Bay Environment. Hdb. Env. Chem., 54: 573-587. Springer International Publishing Switzerland, DOI 10.1007/698_2016_31.

KOGOVŠEK, T., B. BOGUNOVIĆ \& A. MALEJ. 2010. Recurrence of bloom-forming scyphomedusae: wavelet analysis of a 200-year time series. Hydrobiologia, 645: 81-96.

KOGOVŠEK, T., J. H. MOLINERO, D. LUČIĆ, I. ONOFRI, B. GANGAI, M. MILOSLAVIĆ, D. BONNET $\&$ A. MALEJ. 2012. Interannual size changes of adult Aurelia sp.5 medusae stage in the marine protected area of Mljet Island South 
Adriatic. Acta Adriat. 53: 231-240.

KOGOVŠEK, T., M. VODOPIVEC, F. RAICICH, S. UYE \& A. MALEY. 2018. Comparative analysis of the ecosystems in the northern Adriatic Sea and the Inland Sea of Japan: Can anthropogenic pressures disclose jellyfish outbreaks? Sci. Total Environ., 626: 982-994.

LARSON, R. J. 1987. First report of the little-known Scyphomedusa Drymonema dalmatinum in the Caribbean Sea, with notes on its biology. Bull. Mar. Sci., 40: 437-441.

LEVITUS, S., J. I. ANTONOV, T. P. BOYER, R. A. LOCARNINI, H. E. GARCIA \& A. V. MISHONOV. 2009. Global ocean heat content 1955-2008 in light of recently revealed instrumentation problems. Geophys. Res. Lett. 36: L07608, doi:10.1029/2008GL037155.

LUČIĆ, D., B. PESTORIĆ, A. MALEJ, L. LOPEZ-LOPEZ, D. DRAKULOVIĆ, V. ONOFRI, M. MILOSLAVIĆ, B. GANGAI, I. ONOFRI \& A. BENOVIĆ. 2012. Mass occurrence of the ctenophore Bolinopsis vitrea (L. Agassiz, 1860) in the nearshore southern Adriatic Sea (Kotor Bay, Montenegro). Environ. Monit. Assess., 184: 4777-4785.

LUCAS, C.P. W.M. GRAHAM \& C. WIDMER. 2012. Jellyfish life histories: role of polyps in forming and maintaining schyphomedusae populations. Adv. Mar. Biol., 63: 133-196.

LYNAM, C. P., S. J. HAY \& A. S. BRIERLEY. 2004. Interannual variability in abundance of North Sea jellyfish and links to the North Atlantic Oscillation. Limnol. Oceanogr., 49: 637-643. MADIN, L. P. 1991. Distribution and taxonomy of zooplankton in the Alboran Sea and adjacent Western Mediterranean. Technical Report, Wood Hole Oceanographic Institute, WHOI 91-26, 153 pp.

MALEJ, A. 2001. Are irregular plankton phenomena getting more frequent in the northern Adriatic Sea? In: f. Briand (Editor). Gelatinous zooplankton outbreaks: theory and practice. CIESM Workshop Series, 14: 67-68.

MALEJ, A., T. KOGOVŠEK, A. RAMŠAK \& L. CATENACCI. 2012. Blooms and population dynamics of moon jellyfish in the Northern Adriatic. Cah. Biol. Mar., 53: 337-342.

MALEJ, A. M. VODOPIVEC, D. LUČIĆ, I. ONOFRI \&
B. PESTORIĆ. 2014. The lesser-known medusa Drymonema dalmatinum Haeckel 1880 (Scyphozoa, Discomedusae) in the Adriatic Sea. Annales Ser. Hist. Nat., 24: 79-86.

MANDIĆ, S., I. RADOVIĆ \& D. RADOVIĆ. 2017a. Physical and geographical description of the Boka Kotorska Bay. In: A. Joksimović et al. (Editors), The Boka Kotorska Bay Environment. Hdb. Env. Chem., 54: 231-270. Springer International Publishing Switzerland, DOI 10.1007/698_2016_27.

MANDIĆ, M., Z. IKICA \& S. GVOZDENOVIĆ. $2017 \mathrm{~b}$. Mariculture in the Boka Kotorska Bay: tradition, current state and perspective. In: A. Joksimović et al. (Editors), The Boka Kotorska Bay Environment. Hdb. Env. Chem., 54: 231-270. Springer International Publishing Switzerland, DOI 10.1007/698_2016_33.

MARBÀ, N., G. JORDÀ, S. AGUSTI, C. GIRARD \& C. M. DUARTE. 2015. Footprints of climate change on Mediterranean Sea biota. Front. Mar. Sci, 2: 56. doi: 10.3389 /fmars. 2015. 00056.

MILLS, C.E. 2001. Jellyfish blooms: are populations increasing globally in response to changing ocean conditions? Hydrobiologia, 451: 55-68.

NASTAV, B., M. MALEJ, A. MALEJ JR \& A. MALEJ. 2013. Is it possible to determine the economic impact of jellyfish outbreaks on fisheries? A case study - Slovenia. Mediterr. Mar. Sci., 14: 214-223.

PALMIERI, M.G., A. BARAUSSE, T. LUISETTI, \& K. TURNER. 2014. Jellyfish blooms in the Northern Adriatic Sea: Fishermen's perceptions and economic impacts on fisheries. Fish. Res., 155: 51-58.

PESTORIĆ, B, J. KRPO-ĆETKOVIĆ, B. GANGAI, \& D. LUČIĆ. 2012. Pelagic cnidarians in the BokaKotorska Bay (Montenegro, South Adriatic). Acta Adriat., 53:291-302.

PESTORIĆ, B. D. DRAKULOVIĆ, M. HURE, B. GANGAI ZOVKO, I. ONOFRI, P. LUČIĆ \& D. LUČIĆ. 2017. Zooplankton Community in the Boka Kotorska Bay. In: A. Joksimović et al. (Editors), The Boka Kotorska Bay Environment. Hdb. Env. Chem., 54: 231-270. Springer International Publishing Switzerland, DOI 
10.1007/698_2016_35.

POLOCZANSKA, E.S., C. J. BROWN, W. J. SYDEMAN,

W. KIESSLING, D. S. SCHOEMAN, P. J. MOORE,

K. BRANDER. J. F. BRUNO, M. T. BURROWS, C. M. DUARTE, B. S. HALPERN, J. HOLDING, C. V. KAPPEL, M. I. O'CONNOR, J. M. PANDOLFI, C. PARMENSAN, F. SCHWING, A. A. THOMPSON \& A. J. RICHARDSON. 2013. Global imprint of climate change on marine life. Nat. Clim. Chang. 3, 919-925.

PRIETO, L., D. ASTORGA, G. NAVARRO \& J. RUIZ. 2010. Environmental control of phase transition and polyp survival of a massive-outbreaker jellyfish. PLoS ONE, 5: e13793.

PURCELL, J. E. 1991. A review of cnidarians and ctenophores feeding on competitors in the plankton. Hydrobiologia, 206/207: 335-342.

PURCELL, J.E. \& M. N. ARAI. 2001. Interactions of pelagic cnidarians and ctenophores with fish: a review. Hydrobiologia, 451: 27-44.

PURCELL, J.E. \& M.B. DECKER. 2005. Effect of climate on relative predation by scyphomedudsae and ctenophore on copepods in Chesapeake Bay during 1987-2000. Limnol. Oceanogr., 50: 376-387.

PURCELL, J. E., S. UYE \& W. T. LO. 2007. Anthropogenic causes of jellyfish blooms and their direct consequences for humans: a review. Mar. Ecol. Prog. Ser., 350: 153-174.

PURCELL, J.E., D. ATIENZA, V. FUENTES, A. OLARIAGA, U. TILVES, C. COLAHAN \& J. M. GILLI. 2012. Temperature effects on asexual reproduction rates of scyphozoan species from the northwest Mediterranean Sea. Hydrobiologia, 690: 169-180.

RANSON, G. 1945. Les Schyphoméduses de la collection du Museum National d'Historie Naturelle Paris. II. Catalogue raisonné ; origine des récoltés. Bull. Mus. Nat. Hist. Paris, Sér.2, 17: 312-330.

RUSSEL, F.S. 1970. The medusae of the British Isles. Vol. II. Pelagic Scyphozoa with a supplement to the first volume on hydromedusae. Cambridge University Press. London, $284 \mathrm{pp}$.
RICHARDSON, A. J., A. BAKUN, G. C. HAYS \& M. J. GIBBONS. 2009. The jellyfish joyride: causes, consequences and management responses to a more gelatinous future. Trends Ecol. Evol., 24: 312-322.

RUIZ, J., L. PRIETO \& D. ASTROGA, 2012. A model of jellyfish (Cothyloriza tuberculate) outbreaks: a causal analysis in a Mediterranean coastal lagoon. Ecol., Modell., 233: 59-69.

SCORRANO, S., G. AGLIERI, F. BOERO, M. N. DAWSON \& S. PIRAINO. 2016. Unmasking Aurelia species in the Mediterranean Sea: an integrative morphometric and molecular approach. Zool. J. Linn. Soc., https://doi.org/10.1111/ zoj. 12494

UYE, S. 2008. Blooms of the giant jellyfish Nemopilema nomurai: a threat to the fisheries sustainability of the East Asian Marginal Seas. Plankton Benthos Res., 3: 125-131.

VAN WALRAVEN, L. V.T. LANGENBERG, R. DAPPER, J.I. WITTE, A.F. ZUUR \& H. W. VAN DER VEER. 2015. Long-term patterns in 50 years of scyphomedusae catches in the western Dutch Wadden Sea in relation to climate changes and eutrophication. J Plankt. Res., 37: 151167.

VODOPIVEC, M., Á. J. PELIZ \& A. MALEJ. 2017. Offshore marine constructions as propagators of moon jellyfish dispersal. Environ. Res. Lett., 12: doi.org/10.1088/1748-9326/aa75d.

VUKANIĆ, V. 2006. Note of appearance of schyphomedusa Chrysaora hysoscella (Linne, $1766)$ at Bay of Kotor. Natura Montenegrina, 5: 49-53.

WIDMER, C.L. 2005. Effect of temperature on growth of north-east Pacific moon jellyfish ephyrae, Aurelia labiata. J. Mar. Biol. Assoc. U. K., 85: 569-573.

ZAVODNIK, D. 1987. Spatial aggregations of the swarming jellyfish Pelagia noctiluca (Scyphozoa). Mar. Biol, 94: 265-269. 


\title{
Novonastale promjene (2013-2017) faune režnjaka u Bokokotorskom zaljevu, Crna Gora (jugoistočni Jadran)
}

\author{
Ivana VIOLIĆ, Tjaša KOGOVŠEK, Branka PESTORIĆ, Vesna MAČIĆ, \\ Ivona MILIĆ BERAN i Davor LUČIĆ** \\ *Kontakt e-pošta:davor.lucic@unidu.hr
}

\begin{abstract}
SAŽETAK
Semi kvantitativne serije podataka (2013.-2017.) upotrjebljene su za prikaz novonastalih promjena pojave i brojnosti režnjaka u akvatoriju Bokokotorskog zaljeva. Pretpostavljajući da bi globalno zagrijavanje moglo potaknuti promatrane promjene, analizirani su dugoročni trendovi fluktuacija površinske temperature mora. Zabilježeno je šest meroplanktonskih vrsta: Aurelia spp, Chrysaora hysoscella, Cothyloriza tuberculata, Discomedusa lobata, Drymonema dalmatinum i Rhizostoma pulmo. Među njima $C$. hysoscella, i $D$. lobata su bile veoma česte i brojne., formirajući nakupine velikih gustoća tijekom zime i proljeća. Za vrstu $D$. lobata je ujedno prvi poznati opis masovne pojave ove meduze. Vrsta $C$. tuberculata je u akvatoriju bila primijećena tijekom ljeta, a u velikim gustoćama samo u 2017. godini. To je prvi dokumentirani opis masovne pojave ove meduze u Bokokotorskom zaljevu. Pojave mase režnjaka u plankton podudaraju se s visokim odstupanjima površinske temperature mora zabilježenih posljednjih sedam godina. Stoga, naši opisi fenologije i brojnosti režnjaka u Bokokotorskom zaljevu su u skladu s dokazima porasta gustoće populacija želatinoznog zooplanktona na globalnoj skali. Za bolje razumijevanje mehanizma opisanih promjena neophodno je provesti detaljna istraživanja biologije i ekologije bentonskih stadija ovih organizama.
\end{abstract}

Ključne riječi: želatinozni zooplankton, masovne pojave, fenologija, površinske temperature mora, Sredozemno more 
